Article

\title{
Influence of Family Involvement on Family Firm Internationalization: The Moderating Effects of Industrial and Institutional Environments
}

\author{
Lixin Zhou ${ }^{1}$, Yan Han ${ }^{2, *}$ and Chaoli Gou ${ }^{3}$ \\ 1 Research Center for the Economy of the Upper Reaches of the Yangtze River, Chongqing Technology and \\ Business University, Chongqing 400067, China; lxzhou@ctbu.edu.cn \\ 2 School of Management, Chongqing Technology and Business University, Chongqing 400067, China \\ 3 School of Marxism, Chongqing Technology and Business University, Chongqing 400067, China; \\ clgou@ctbu.edu.cn \\ * Correspondence: hanyan@ctbu.edu.cn
}

Received: 8 September 2019; Accepted: 11 October 2019; Published: 16 October 2019

\begin{abstract}
This paper aimed to explore the effects of family ownership and management on Chinese family firm internationalization, and to examine the moderating effects of environmental munificence, institutional environment, and political ties in this relationship. A questionnaire survey of 274 family firms in 8 provinces or municipalities in China was conducted to test the proposed hypotheses empirically. The results were as follows: First, family ownership and management positively impacted the depth and breadth of internationalization. Second, environmental munificence weakened the effect of family ownership on the depth of internationalization, as well as on the effect of family management on the breadth of internationalization, but intensified the effect of family management on the depth of internationalization. Third, the institutional environment intensified the effects of family management on the depth and breadth of internationalization. Finally, political ties weakened the effect of family management on the depth of internationalization, but intensified the effect of family ownership on the breadth of internationalization. The contributions and implications of this study are also discussed.
\end{abstract}

Keywords: family firm; internationalization; family involvement; environmental munificence; institutional environment; political ties

\section{Introduction}

Research efforts on family firm internationalization in developed economies are increasingly focusing on the influence of family involvement on a firm's internationalization [1]. However, empirical evidence on this question is inconclusive. For example, is there a positive relationship [2,3], negative relationship [4,5], curvilinear relationship [6], or no relationship [7,8]? One plausible reason for the mixed results is that most studies use different measures for family involvement and internationalization, and another reason might be the diverse country contexts that existed across previous studies [9].

We observe that emerging economies such as China have a ubiquitous presence of family firms. A distinguishing characteristic of these family firms is the strong presence of a family that controls a large percentage of the firm's equity and management. Therefore, it is evident that the family will exert an important impact on the internationalization of Chinese family firms. However, little research has analyzed the influence of family involvement variables such as family ownership and/or management on the internationalization of Chinese family firms. Furthermore, the very limited research on Chinese family firms ignores the effects of industrial and institutional environments on relative relationships $[10,11]$. 
As proposed in numerous previous studies, it is essential to consider the effects of environment on family firm internationalization. For example, Debick [12] noted that the industrial environment (i.e., environmental munificence) can affect the relationship between socioemotional wealth and family firm internationalization. Emerging economies such as China are typically characterized by poorer governance, as well as weaker and less efficient formal institutions. These profound differences in institutional frameworks between emerging and developed economies have led scholars to pay more attention to how the institutional environment impacts the internationalization of Chinese private firms, which are mostly family firms. In this stream of research, there have emerged two contrasting arguments, which can be summarized as an escape view and a fostering view. The escape view suggests that the internationalization of Chinese private firms seems to be an escape from the institutional constraints in the home country $[13,14]$, whereas the fostering view contends that the government is fostering a favorable institutional setting to promote internationalization of Chinese private firms [14]. Moreover, Chinese private firms have a strong tendency to establish close ties with government agencies and officials. Therefore, scholars are also interested in questions such as how informal institutions such as political ties $[15,16]$ affect the internationalization of Chinese firms [14].

The resource-based view assumes that family ownership is a special resource that can provide Chinese family firms with the necessary resources for internationalization. Agency theory holds that family management can effectively reduce the agency costs between family owners and managers in the internationalization process of family firms. Therefore, family ownership and management can influence the internationalization of Chinese family firms.

An institution-based perspective contends that formal and informal institutions influence firms' internationalization in emerging economies. In China, the government is fostering a favorable institutional setting to promote family firm internationalization. Furthermore, political ties, as an important substitute for informal institutions [15,16], may help Chinese family firms to receive regulatory resources and policy support. Therefore, formal and informal institutions might impact the relationship between family involvement and Chinese family firm internationalization.

The contributions of this paper are as follows: First, this paper extends current research on antecedents of family firm internationalization in emerging economies to research linkage among family involvement, industrial environment, institutional environment (i.e. formal institution), and political ties (i.e., informal institution). More specifically, we examine the effects of family ownership and management on Chinese family firm internationalization (i.e., internationalization depth and internationalization breadth), as well as the moderating effects of environmental munificence, the institutional environment, and political ties in this relationship. Internationalization depth is often conceptualized as the extent of its foreign operations and investments, and is calculated as the ratio of export sales to total sales [17]. Internationalization breadth is defined as the firm's scope of international operations, and is often calculated as the number of countries in which the firm operates [17]. Drawing upon the data of family firms in eastern and western China, our results highlight the importance of family characteristics and the external environment on the internationalization of Chinese family firms.

Second, this paper demonstrates the importance of institutional environment on the internationalization of Chinese family firms. Different from traditional analysis of institution, which emphasizes formal institution, this paper considers both formal and informal institutions by highlighting the moderating effects of the degree of marketization and political ties. Furthermore, we find that entrepreneurs' political ties can weaken the positive effect of family management on the depth of internationalization, but intensify the positive effect of family ownership on the breadth of internationalization. Thus, our findings confirm the positive and negative effects of political ties on Chinese firms. Most previous research has focused on the positive effect of political ties on Chinese firms $[18,19]$. Therefore, this study also adds novel insights into the research on entrepreneurs' political ties in emerging economies. 
Third, this paper distinguishes two different types of internationalization strategies (i.e., internationalization depth and internationalization breadth), as well as two different types of family involvement variables (i.e., family ownership and family management), thus providing a more nuanced understanding of the impact of family involvement on Chinese family firm internationalization.

\section{Hypotheses}

\subsection{The Effect of Family Involvement on Chinese Family Firm Internationalization}

\subsubsection{The Effect of Family Ownership on Chinese Family Firm Internationalization}

The effect of family ownership on internationalization is ambiguous, yielding findings that range from negative to positive ones [1]. A resources-based view suggests that external (non-family) resources provide the push that family firms need to achieve successful internationalization outcomes [20], especially financial resources from non-family owners [4]. When family owners have large shares in the firm, it implies that family firms are less likely to accept external debt and equity investment [21]; thus, family firms often lack the financial resources required for internationalization. This lack of financial resources has a negative impact on internationalization efforts [21]. Agency theory holds that family firms can be conservative and risk-averse [22]. As internationalization is often associated with high risks and uncertain returns [4,23], family firms with higher family ownership are less likely to engage in international activities. Most empirical studies support the negative effect of family ownership on the internationalization of family firms $[4,24,25]$. However, higher family ownership also means that family firms may acquire more family resources for internationalization, and that family owners have a strong tendency to monitor managers so as to reduce the agency cost in the internationalization process. Therefore, family ownership may positively affect family firm internationalization, which is supported by a few empirical studies [2,3,26]. Additionally, some empirical studies also support a curvilinear relationship between family ownership and internationalization [6].

During China's economic transition, we assume that family ownership may facilitate family firms to internationalize. First, family ownership is a special resource that can provide Chinese family firms with the needed resources for internationalization. A resource-based view assumes that family-specific resources, such as family human capital, social capital, patient capital, and survivability capital [27], are important resource bases for international expansion of family firms. Patient capital can be described as invested capital without the threat of liquidation for long periods. Survivability capital refers to pooled personal resources that family members loan, contribute, and share with the business. The possession of patient capital and survivability capital can allow family firms to be strategically flexible in pursuing opportunities available in the international market [28], and family firms may consider expanding their business abroad through strategic flexibility [28]. In particular, most family firms in China tend to internationalize their business through exporting activities at present [29], which requires fewer financial resources and management capabilities than other internationalization methods. An imperfect institutional environment increases the dependence of Chinese family firms on family-specific resources. Thus, Chinese family firms might compensate for their weaknesses regarding internationalization through family-specific resources. Second, Chinese family firms are characterized by weak organization and strong linkages [30], that is, Chinese family firms have a strong tendency to establish external network relationships with customers, business partners, governmental institutions, as well as other stakeholders through family and pan-family guanxi (e.g., family, friends, classmates, colleagues, and ally relationships). Chinese family firms are able to acquire the needed resources through network relationships [30]. Family firms may also capitalize on their well-established names and connections to other foreign family firms [31] to reduce their barriers to internationalization. On the basis of the above arguments, we hypothesize:

Hypothesis 1a (H1a): Family ownership has a significantly positive effect on Chinese family firm internationalization. 


\subsubsection{The Effect of Family Management on Chinese Family Firm Internationalization}

Family management has a different effect on the internationalization of family firms. The firms with high levels of family management often have more family managers in the top management team. In a family firm, family managers are generally appointed on the basis of kinship rather than on their management talent. Moreover, family managers typically have limited social and political ties in foreign markets compared to nonfamily professionals [32,33], thus limiting the access for international knowledge and opportunities. Therefore, the firms with high levels of family management often lack of managerial capabilities and international market knowledge, which are fundamental for family firms to overcome the uncertainties in the internationalization process [34]. Most empirical studies support the viewpoint that family management has a negative effect on family firm internationalization $[5,8,25]$. However, family involvement in management may facilitate family firms to internationalize, mainly because of the lower agency costs in the internationalization process and the lower family members' perceived risks with complex investment decisions that accompany internationalization [2]. This view is supported by a few empirical studies [2]. Additionally, empirical studies also support a curvilinear relationship between family management and internationalization [10].

During China's economic transition, we propose that family management may positively affect the internationalization of Chinese family firms. Firstly, a distinguishing characteristic of Chinese family firms is the strong presence of an owner family that controls a large percentage of the firm's equity. Family involvement in management implies that family owners' interests are highly aligned with managers' interests, as well as the interests of family firms. It can effectively reduce the agency costs between family owners and managers in the internationalization process. Secondly, in the underdeveloped market of professional managers, the arrangement of trusted relatives in key positions can stimulate them to contribute their network resources, and Chinese family firms can then benefit from this result. Thirdly, Chinese family firms often choose to get internationalized with exporting activities [29], which require fewer management capabilities than other internationalization modes. Therefore Chinese family management might meet their needs for management capabilities regarding internationalization. Finally, family involvement in management means long tenure of family managers in the firm, and long tenure can lead Chinese family firms to focus on long-term growth strategies such as an internationalization strategy. On the basis of the above arguments, we hypothesize:

Hypothesis $1 \mathbf{b}$ (H1b): Family management has a significantly positive effect on Chinese family firm internationalization.

\subsection{The Moderating Effect of Environmental Munificence}

We argue that environmental munificence can influence the relationship between family involvement and the internationalization of the Chinese family firm. In terms of resources, family involvement in business might lead to a lack of the needed resources for internationalization $[4,5,21]$. Family involvement in ownership in particular may lead family firms to prefer family and internal equity financing, and to avoid external debt and equity financing [21], thus leading family firms to lack the financial resources required for internationalization. Family involvement in management may make family firms prefer hiring family managers and be reluctant to introduce non-family managers with management capabilities and international market knowledge. Family firms may complement their limited resources by identifying and utilizing external resources. Therefore, resource availability in the environment directly determine the acquisition of external resources for family firms. Dess and Beard [35] suggest that environmental munificence mainly refers to the scarcity or abundance of available resources in the environment. When there is a situation of high environmental munificence, family firms have more access to the resources, as well as the lower transaction costs required to access the resources. Therefore, in the condition of high environmental munificence, family firms can acquire more conveniently and cheaply scarce resources required for internationalization. This resource 
support from the industrial environment will reduce resource supply effect and resource constraints due to family involvement in the firm, thus promoting family firms to internationalize their business. Therefore, we hypothesize:

Hypothesis 2 (H2): Environmental munificence weakens the effect of family involvement on Chinese family firm internationalization, that is, as environmental munificence increases, the effect of family involvement on Chinese family firm internationalization becomes weaker.

\subsection{The Moderating Effect of Institutional Environment}

Institutions are commonly recognized as providing rules, both formal (e.g., regulations, laws) and informal (e.g., codes of conduct, norms), that dictate how firms operate [36]. An institution-based perspective assumes that institutional environment in the home country influences firms' internationalization strategies in emerging economies [37,38]. For example, the governments in emerging economies encourage or constrain firms' internationalization by formulating international policies, such as export trade and FDI (Foreign Direct Investment) policies. During China's economic transition, family firms are usually faced with institutional constraints $[14,39]$, which are typically characterized by a poorer legal system, weak property protection, imperfect financing system, and an underdeveloped market of professional managers. Therefore, acquisition of resources needed for expanding into international markets is costly. A well-developed institutional environment contains many intermediaries, such as credit-rating agencies, investment analysts, merchant bankers, and search and recruiting agencies. It also has a perfect financing system and professional manager market. Therefore, family firms are likely to acquire various resources, knowledge, and information more effectively, and reduce the transaction costs resulting from institutional discrimination and institutional gap. Moreover, a well-developed institutional environment may provide family firms with more effective property protection and patent protection regarding international operation, and thus it directly facilitates the export of products with higher technical complexity, as well as ensuring the protection of intellectual property and the implementation of contracts required for outsourcing. Consequently, family firms in a well-developed institutional environment are more likely to internationalize.

During China's economic transition, the effect of family involvement on internationalization is dependent on the institutional environment. In a well-developed institutional environment, family firms are more likely to acquire access to resources, and these family firms are also more likely to pursue a long-term orientation strategy. The interactive effect of a well-developed institutional environment with family involvement may lead family firms to choose an internationalization strategy with a long-term orientation. Therefore, we hypothesize:

Hypothesis 3 (H3): The institutional environment intensifies the effect of family involvement on Chinese family firm internationalization, that is, as the institutional environment improves, the effect of family involvement on Chinese family firm internationalization becomes stronger.

\subsection{The Moderating Effect of Political Ties}

An institution-based perspective suggests that guanxi is an important substitute for formal institution [15,16]. During the economic transition in China, various government agencies and officials enjoyed a high degree of power and discretion in the interpretation and enforcement of relevant policies or even in direct intervention in business activities [40]. Political ties with government agencies or officials have important implications for Chinese family firm internationalization. When an institutional environment is imperfect, Chinese family firms need to rely more on network or relation-based strategies to develop the ability to fill the institutional voids [41]. In China, the most 
direct and effective means for family entrepreneurs to build political ties is to become deputies at various levels in the People's Congress or members of the Chinese People's Political Consultative Conference. The benefits of political ties are supposed to mainly be reflected in three aspects, that is, resource and policy support, as well as legitimacy enhancement [42]. First, political ties may help family firms to receive regulatory resources and policy support, such as industry or market access, policy information related to export and OFDI(Outward Foreign Direct Investment), tax relief, government subsidies, land, and bank credits $[18,19]$, thus reducing resources and capacity constraints due to an imperfect market and redistribution system. Second, political ties facilitate family firms in connecting with successful organizations, such as large state-owned enterprises with a well-established presence overseas or scientific institutions and universities with an international reputation, thus enhancing family firm legitimacy in overseas markets. High legitimacy facilitates a family firm's access to resources in a developed market, and directly enhances the cooperation and willingness of technology suppliers [43]. Moreover, through building political ties with government agencies or officials, family firms have also accumulated some skills and strategies to deal with government agencies and officials. These skills and strategies can be brought into overseas markets, which help family firms deal with the relationship with overseas government agencies or officials. However, as a double-edged sword, political ties also have negative effects, for example, the establishment of political ties may cost a lot of rent and put pressure on the firm's resources [44], thus increasing the transaction cost of international activities.

During China's economic transition, although political ties have some negative effects on family firms, they can exert resource compensation by integrating various resources. The richer the political ties that family firms have, the more likely they are to utilize political ties to acquire scarce resources and policy support required for internationalization. Therefore, we hypothesize:

Hypothesis 4 (H4): Political ties intensify the effect of family involvement on Chinese family firm internationalization, that is, as political ties increase, the effect of family involvement on Chinese family firm internationalization becomes stronger.

To sum up, the research model of this paper is shown in Figure 1.

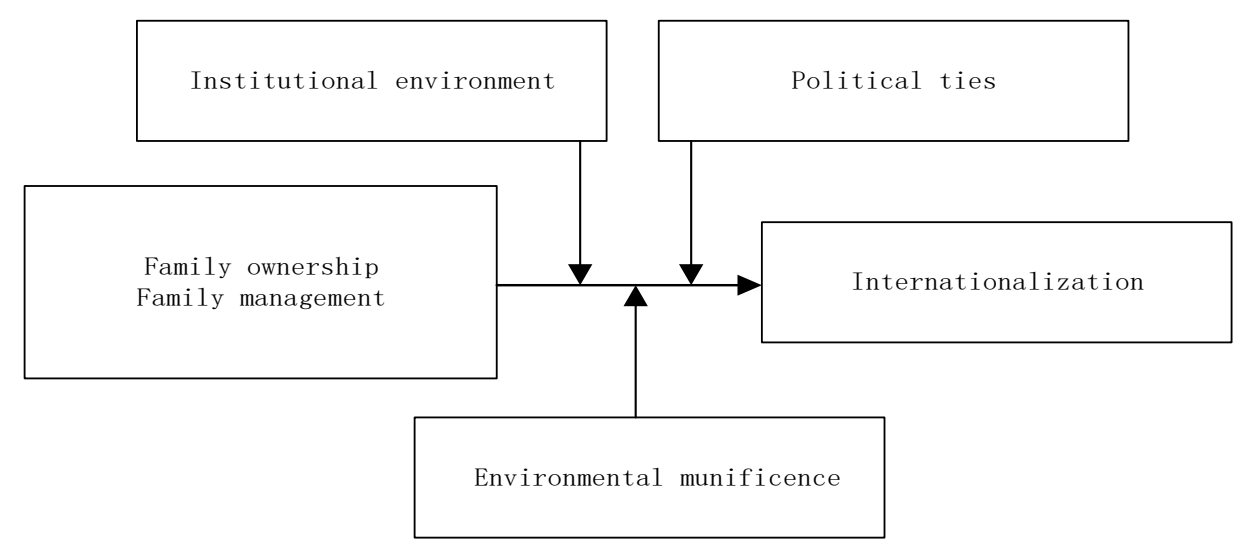

Figure 1. Research model.

\section{Methodology}

\subsection{Data and the Sample}

This study uses the empirical data from a survey of Chinese private firms in 2016. The survey was conducted by the Research Center for the Economy of the Upper Reaches of the Yangtze River at Chongqing Technology and Business University. The questionnaires were delivered to various counties and cities in Zhejiang, Shanghai, Fujian, Guangdong, Chongqing, Qinghai, Shaanxi, and Yunnan 
provinces or municipalities. Among of them, four are in the east of China, and the other four are in the west of China. These provinces are representative of the most-developed and the least-developed parts of the private economy in China, as well as representative of the highest and the lowest degree of marketization in China. Meanwhile, our survey had no specific requirement for firm size, firm year, and industry, or other related factors, thus ensuring that it was a representative sample. The selection of the initial sample was of private firms with international business, such as exporting and overseas FDI activities. The respondents were in dominant management positions, such as owners, family CEOs, financial managers, and administrative managers. To ensure the quality, a team of graduate assistants was hired to personally visit the firms and urge them to complete the questionnaires. Of the 350 distributed questionnaires, 342 were returned. This study identified a family firm according to the following criterion - that a single family owns at least $50 \%$ of the equity [45]. Thus, 274 valid samples of family firms were selected, with the effective rate being $80.12 \%$.

Sampled firms were located in eight provinces or municipalities, but mainly in Zhejiang (38.7\%) and Chongqing (36.5\%). These firms operated in four industries, including manufacturing, service, agriculture, and farming, as well as construction, but mainly in the manufacturing industry $(77.4 \%)$. In all, $48.9 \%$ of the sampled firms were under 50 in their total staff, and $87.6 \%$ of sampled firms were under 20 years old. A total of $83.9 \%$ of the sampled firms had male owners, $77.0 \%$ of owners were in the age range of $36-55$ years, and $19.4 \%$ of owners or senior managers had political ties. Among the sampled firms, $51.5 \%$ had a single family holding of $100 \%$ of the ownership, and $92.3 \%$ of the sampled firms had at least one family member in the top management team. The detailed information of the sampled firms is shown in Table 1.

Table 1. Demographic characteristics of the sample.

\begin{tabular}{|c|c|c|c|c|c|}
\hline Items & Frequency & Percentage $(\%)$ & Items & Frequency & Percentage $(\%)$ \\
\hline Location & & & Entrepreneur's gender & & \\
\hline Zhejiang & 106 & 38.7 & Male & 229 & 83.9 \\
\hline Shanghai & 15 & 5.5 & Female & 44 & 16.1 \\
\hline Fujian & 6 & 2.2 & Entrepreneur's age & & \\
\hline Guangdong & 4 & 1.5 & Less than 35 years & 37 & 13.5 \\
\hline Chongqing & 100 & 36.5 & $36-45$ years & 128 & 46.7 \\
\hline Qinghai & 22 & 8.0 & $46-55$ years & 83 & 30.3 \\
\hline Shaanxi & 13 & 4.7 & Over 55 years & 26 & 9.5 \\
\hline Yunnan & 8 & 2.9 & $\begin{array}{c}\text { People's Congress Member, } \\
\text { or Member of Chinese } \\
\text { People's Political } \\
\text { Consultative Conference }\end{array}$ & & \\
\hline Industry & & & Yes & 53 & 19.4 \\
\hline Manufacturing & 212 & 77.4 & No & 220 & 80.6 \\
\hline Service & 46 & 16.8 & Family ownership & & \\
\hline $\begin{array}{l}\text { Agriculture, } \\
\text { farming }\end{array}$ & 12 & 4.4 & $50 \%-70 \%$ & 72 & 26.3 \\
\hline Construction & 4 & 1.5 & $71 \%-99 \%$ & 61 & 22.3 \\
\hline Total staff & & & $100 \%$ & 141 & 51.5 \\
\hline Less than 50 & 134 & 48.9 & Family management & & \\
\hline $51-200$ & 80 & 29.2 & $0 \%$ & 21 & 7.7 \\
\hline 201-300 & 18 & 6.6 & $0 \%-20 \%$ & 112 & 41.2 \\
\hline More than 301 & 42 & 15.3 & $21 \%-50 \%$ & 44 & 16.2 \\
\hline Firm age & & & $51 \%-80 \%$ & 43 & 15.8 \\
\hline Less than 5 years & 50 & 18.2 & More than $80 \%$ & 52 & 19.1 \\
\hline $6-10$ years & 89 & 32.5 & International experience & & \\
\hline $11-19$ years & 101 & 36.9 & Yes & 200 & 73.5 \\
\hline More than 20 years & 34 & 12.4 & No & 72 & 26.5 \\
\hline
\end{tabular}

\subsection{Measures}

\subsubsection{Dependent Variable}

The dependent variable, that is, internationalization, was measured by two dimensions: internationalization depth and internationalization breadth. In this paper, internationalization depth 
(DEPT) was measured by the ratio of export sales to total sales in 2015. Internationalization breadth (BREA) was measured by a natural logarithm of the number of countries and regions involved in firms' product export and overseas FDI in 2015.

\subsubsection{Independent Variable}

The independent variable, that is, family involvement, was measured by two dimensions: family ownership and family management. Family ownership (FO) was measured by the percentage of total shares owned by family members. Family management (FM) was measured by the ratio of family members to non-family members in the top management teams. The survey specified five categories: $0 \%, 0 \%-20 \%, 21 \%-50 \%, 51 \%-80 \%$, and more than $80 \%$, and took values from 1 to 5 corresponding to those five categories.

\subsubsection{Moderating Variables}

Environmental munificence (EM) was measured using Debicki's [12], that is, (1) very safe, with little threat to the survival and well-being of our firm; (2) there is an abundance of investment and marketing opportunities that can be easily exploited; and (3) in an industry with little competition and few hindrances. A five-point Likert scale was used, ranging from strongly disagree (1), to strongly agree (5). The measure demonstrated acceptable reliability (Cronbach's alpha $=0.794$ ).

Institutional environment (IE) was measured by the marketization index of China's provinces or municipalities in 2014 [46]. The index included five categories of indicators, that is, (1) the relationship between government and market; (2) the development of the non-state-owned economy; (3) the degree of product market development; (4) the degree of factor market development; and (5) the development of market intermediary organizations and the legal system environment. In China, there is a great difference between the marketization index in each province or municipality. Currently, many scholars have used this index as a substitute variable for the institutional environment (i.e., formal institution) in each province or municipality of China [47].

Political ties (POL) was indicated by a dummy variable, with a value of 1 if the firm's owners or senior managers were members of the People's Congress or Chinese People's Political Consultative Conference, and 0 otherwise.

\subsubsection{Control Variables}

The control variables of this study included the firm's size, firm's age, industry type, international experience, and past performance $[4,6,20,24,48]$. Firm size (SIZE) was measured by the natural logarithm of the number of employees in 2015. Firm age (AGE) was measured by the natural logarithm of the year when the firm was established. Industry type (INDU) was measured by a dummy variable, with 1 for a manufacturing industry, and 0 otherwise. International experience (EIE) was measured by a dummy variable, with a value of 1 if the firm's owner or senior managers had experienced overseas study, life, work, or had business trips, and 0 otherwise. Past performance (PERF) was measured by asking the respondents to compare their firm's performance with domestic competitors over the past 3 years in terms of sales growth rate, profit growth rate, market share growth rate, and return on total assets, using a five-point Likert scale ranging from very bad (1) to very good (5). The measure demonstrated acceptable reliability (Cronbach's alpha $=0.874)$.

\section{Results}

\subsection{Descriptive Statistics and Correlation Analysis}

Table 2 presents the descriptive statistics and correlation coefficients for the research variables. The correlation between internationalization (i.e., internationalization depth and internationalization breadth) and family involvement (i.e., family ownership and family management) was positive and significant $(p<0.01)$. The correlation between internationalization depth and environmental 
munificence was positive and significant $(p<0.05)$. The correlation between internationalization depth and institutional environment was positive and significant $(p<0.001)$. The correlation between internationalization breadth and institutional environment was positive and significant $(p<0.05)$. The correlation between internationalization depth and political ties was negative and significant $(p<0.01)$.

Table 2. Descriptive statistics and correlation coefficient.

\begin{tabular}{|c|c|c|c|c|c|c|c|c|c|c|c|c|c|}
\hline Variables & Mean & SD & 1 & 2 & 3 & 4 & 5 & 6 & 7 & 8 & 9 & 10 & 11 \\
\hline 1.DEPT & 0.459 & 0.385 & 1 & & & & & & & & & & \\
\hline 2.BREA & 1.243 & 0.977 & $0.304^{* * *}$ & 1 & & & & & & & & & \\
\hline 3.FO & 0.851 & 0.185 & $0.239 * * *$ & $0.163 * *$ & 1 & & & & & & & & \\
\hline 5.EM & 2.736 & 0.827 & 0.123 * & -0.078 & 0.030 & 0.031 & 1 & & & & & & \\
\hline 6.IE & 8.120 & 2.061 & $0.356^{* * *}$ & $0.142 *$ & 0.090 & $0.394^{* * *}$ & 0.017 & 1 & & & & & \\
\hline 7.POL & 0.194 & 0.396 & $-0.184 * *$ & 0.050 & $-0.107^{+}$ & $-0.160^{* *}$ & -0.014 & $-0.346^{* * *}$ & 1 & & & & \\
\hline 8. SIZE & 4.163 & 1.575 & $-0.339^{* * *}$ & 0.075 & $-0.256^{* * *}$ & $-0.248^{* * *}$ & -0.029 & $-0.259 * * *$ & $0.370 * * *$ & 1 & & & \\
\hline 11.EIE & 0.735 & 0.442 & 0.031 & $0.137 *$ & -0.067 & $-0.146^{*}$ & -0.120 * & -0.041 & 0.081 & 0.071 & $0.129 *$ & 0.007 & 1 \\
\hline 12.PERF & 3.295 & 0.749 & $0.104^{+}$ & $0.164^{* *}$ & 0.009 & 0.018 & $0.144 *$ & 0.088 & $0.128 *$ & $0.105^{+}$ & -0.043 & 0.026 & $0.144 * *$ \\
\hline
\end{tabular}

\subsection{Test of Hypotheses}

All hypotheses were tested using hierarchical regressions. To test the hypothesized moderating effects, we constructed the interactions between environmental munificence, institutional environment, political ties, and family involvement (i.e., family ownership and family management). In order to minimize multicollinearity, we used the mean-centered variables to create the interactions [49]. The multicollinearity test found that the maximum of variance inflation factor score was 2.023, suggesting that multicollinearity was not an issue in our analyses [50].

\subsubsection{The Effect of Family Involvement on Chinese Family Firm Internationalization}

Model 1 of Tables 3 and 4 is our baseline model that included only control variables. In Model 2 of Tables 3 and 4, we tested the direct effect of family involvement on Chinese family firm internationalization. In Model 2 of Table 3, it was found that family ownership and management had significantly positive effects on internationalization depth $(\beta=0.243, p<0.05 ; \beta=0.069, p<0.001)$. In Model 2 of Table 4, we found that family ownership and management had significantly positive effects on internationalization breadth $(\beta=0.731, p<0.05 ; \beta=0.142, p<0.01)$. The results were still robust considering the moderating effects of environmental munificence, institutional environment, and political ties (see Model 3, Model 4, Model 5, and Model 6). Thus, our result was in line with previous research $[2,3,26]$, but it did not support the viewpoint that family management negatively impacts on family firm internationalization $[5,8,25]$. This positive effect was likely due to lower agency cost, as well as more family and network resources resulting from family involvement in ownership and management. Therefore, Hypotheses $1 \mathrm{a}$ and $1 \mathrm{~b}$ were both supported.

Table 3. Results of family involvement on the internationalization depth of Chinese family firms.

\begin{tabular}{ccccccc}
\hline Variables & Model 1 & Model 2 & Model 3 & Model 4 & Model 5 & Model 6 \\
\hline -CONS & $-0.064(0.161)$ & -0.385 & -0.336 & -0.482 & -0.340 & -0.379 \\
& $-0.077^{* * *}$ & $-0.188)$ & $+(0.188)$ & $*(0.189)$ & $+(0.188)$ & $*(0.192)$ \\
SIZE & $(0.016)$ & $* * *(0.016)$ & -0.065 & -0.059 & -0.058 & -0.062 \\
& $0.041(0.033)$ & $0.032(0.033)$ & $0.033(0.033)$ & $0.034(0.033)$ & $0.031(0.033)$ & $0.034(0.032)$ \\
AGE & $0.044(0.054)$ & $0.052(0.053)$ & $0.051(0.053)$ & $0.042(0.053)$ & $0.044(0.053)$ & $0.040(0.052)$ \\
INDU & $0.045(0.049)$ & $0.071(0.048)$ & $0.065(0.049)$ & $0.075(0.048)$ & $0.080(0.049)$ & $0.069(0.048)$ \\
EIE & $0.051^{+}(0.030)$ & $0.043(0.029)$ & $0.059 *(0.029)$ & $0.036(0.029)$ & $0.035(0.029)$ & $0.046(0.029)$ \\
PERF & & & & &
\end{tabular}


Table 3. Cont.

\begin{tabular}{|c|c|c|c|c|c|c|}
\hline Variables & Model 1 & Model 2 & Model 3 & Model 4 & Model 5 & Model 6 \\
\hline EM & $0.047^{+}(0.026)$ & $\begin{array}{c}0.047 \\
+(0.025)\end{array}$ & $\begin{array}{c}0.046 \\
+(0.025)\end{array}$ & $\begin{array}{c}0.042 \\
+(0.025)\end{array}$ & $\begin{array}{c}0.048 \\
+(0.025)\end{array}$ & $\begin{array}{c}0.042 \\
+(0.025)\end{array}$ \\
\hline IE & $0.048^{* * *}(0.011)$ & $0.031 *(0.012)$ & $0.025 *(0.012)$ & $\begin{array}{c}0.047 \\
* * *(0.013)\end{array}$ & $0.031 *(0.012)$ & $\begin{array}{c}0.040 \\
* *(0.014)\end{array}$ \\
\hline POL & $0.001(0.060)$ & $-0.005(0.059)$ & $-0.014(0.058)$ & $0.020(0.059)$ & $-0.040(0.062)$ & $-0.006(0.064)$ \\
\hline $\mathrm{FO}$ & & $0.243 *(0.118)$ & $\begin{array}{c}0.211 \\
+(0.119)\end{array}$ & $0.264 *(0.118)$ & $\begin{array}{c}0.226 \\
+(0.119)\end{array}$ & $\begin{array}{c}0.206 \\
+(0.119)\end{array}$ \\
\hline FM & & $\begin{array}{c}0.069 \\
* * *(0.018)\end{array}$ & $\begin{array}{c}0.069 \\
* * *(0.018)\end{array}$ & $0.049 *(0.019)$ & $\begin{array}{c}0.065 \\
* * *(0.018)\end{array}$ & $\begin{array}{c}0.050 \\
* *(0.019)\end{array}$ \\
\hline $\mathrm{FO} \times \mathrm{EM}$ & & & $\begin{array}{c}-0.292 \\
*(0.142)\end{array}$ & & & $\begin{array}{c}-0.309 \\
*(0.141)\end{array}$ \\
\hline $\mathrm{FM} \times \mathrm{EM}$ & & & $0.041 *(0.020)$ & & & $\begin{array}{c}0.035 \\
+(0.020)\end{array}$ \\
\hline $\mathrm{FO} \times \mathrm{IE}$ & & & & $0.039(0.054)$ & & $0.040(0.056)$ \\
\hline $\mathrm{FM} \times \mathrm{IE}$ & & & & $0.027 *(0.011)$ & & $0.023 *(0.011)$ \\
\hline $\mathrm{FO} \times \mathrm{POL}$ & & & & & $0.053(0.268)$ & $0.243(0.277)$ \\
\hline $\mathrm{FM} \times \mathrm{POL}$ & & & & & $\begin{array}{l}-0.098 \\
*(0.049)\end{array}$ & $\begin{array}{c}-0.067 \\
+(0.051)\end{array}$ \\
\hline$R^{2}$ & 0.219 & 0.277 & 0.296 & 0.299 & 0.288 & 0.322 \\
\hline Adjusted $R^{2}$ & 0.196 & 0.249 & 0.263 & 0.266 & 0.255 & 0.279 \\
\hline$F$ & $9.174 * * *$ & $9.849^{* * *}$ & $8.945^{* * *}$ & $9.047^{* * *}$ & $8.606^{* * *}$ & $7.453^{* * *}$ \\
\hline$N$ & 270 & 268 & 268 & 268 & 268 & 268 \\
\hline
\end{tabular}

Notes: $+p<0.10 ;{ }^{*} p<0.05 ;{ }^{* *} p<0.01 ;{ }^{* * *} p<0.001$.

Table 4. Results of family involvement on the internationalization breadth of Chinese family firms.

\begin{tabular}{|c|c|c|c|c|c|c|}
\hline Variables & Model 1 & Model 2 & Model 3 & Model 4 & Model 5 & Model 6 \\
\hline -CONS & $-0.575(0.442)$ & $-1.393^{* *}(0.517)$ & $-1.331 *(0.519)$ & $-1.456^{* *}(0.525)$ & $-1.310 *(0.515)$ & $-1.449^{* *}(0.527)$ \\
\hline SIZE & $-0.025(0.045)$ & $0.019(0.046)$ & $0.012(0.046)$ & $0.025(0.046)$ & $0.012(0.046)$ & $0.008(0.046)$ \\
\hline AGE & $0.333^{* *}(0.096)$ & $0.288^{* *}(0.096)$ & $0.305^{* *}(0.096)$ & $0.276^{* *}(0.096)$ & $0.272 * *(0.095)$ & $0.289^{* *}(0.095)$ \\
\hline INDU & $0.177(0.150)$ & $0.199(0.148)$ & $0.219(0.147)$ & $0.194(0.148)$ & $0.222(0.146)$ & $0.230(0.145)$ \\
\hline EIE & $0.155(0.134)$ & $0.209(0.134)$ & $0.170(0.135)$ & $0.211(0.133)$ & $0.174(0.133)$ & $0.128(0.133)$ \\
\hline PERF & $0.215 *(0.081)$ & $0.197 *(0.079)$ & $0.184 *(0.081)$ & $0.184 *(0.079)$ & $0.180 *(0.079)$ & $0.153^{+}(0.080)$ \\
\hline EM & $-0.118(0.071)$ & $-0.124+(0.069)$ & $-0.126^{+}(0.069)$ & $-0.144 *(0.070)$ & $-0.117^{+}(0.068)$ & $-0.136 *(0.069)$ \\
\hline $\mathrm{IE}$ & $0.062^{+}(0.031)$ & $0.026(0.033)$ & $0.027(0.034)$ & $0.052(0.037)$ & $0.039(0.033)$ & $0.081 *(0.038)$ \\
\hline POL & $0.121(0.167)$ & $0.116(0.165)$ & $0.115(0.164)$ & $0.140(0.167)$ & $0.242(0.172)$ & $0.332+(0.179)$ \\
\hline $\mathrm{FO}$ & & $0.731 *(0.332)$ & $0.688 *(0.333)$ & $0.739 *(0.332)$ & $0.610^{+}(0.331)$ & $0.593+(0.331)$ \\
\hline FM & & $0.142 * *(0.050)$ & $0.148^{* *}(0.049)$ & $0.107 *(0.054)$ & $0.151^{* *}(0.049)$ & $0.109 *(0.053)$ \\
\hline $\mathrm{FO} \times \mathrm{EM}$ & & & $-0.220(0.392)$ & & & $-0.272(0.386)$ \\
\hline $\mathrm{FM} \times \mathrm{EM}$ & & & $-0.114 *(0.056)$ & & & $-0.112 *(0.055)$ \\
\hline $\mathrm{FO} \times \mathrm{IE}$ & & & & $-0.158(0.150)$ & & $0.005(0.153)$ \\
\hline $\mathrm{FM} \times \mathrm{IE}$ & & & & $0.053+(0.031)$ & & $0.070 *(0.031)$ \\
\hline $\mathrm{FO} \times \mathrm{POL}$ & & & & & $2.148^{* *}(0.733)$ & $2.375^{* *}(0.762)$ \\
\hline $\mathrm{FM} \times \mathrm{POL}$ & & & & & $0.067(0.136)$ & $0.124(0.141)$ \\
\hline$R^{2}$ & 0.119 & 0.173 & 0.190 & 0.184 & 0.202 & 0.235 \\
\hline Adjusted $R^{2}$ & 0.095 & 0.139 & 0.149 & 0.143 & 0.162 & 0.183 \\
\hline$F$ & $4.361^{* * *}$ & $5.073^{* * *}$ & $4.702^{* * *}$ & $4.527^{* * *}$ & $5.090^{* * *}$ & \\
\hline$N$ & 256 & 254 & 254 & 254 & 254 & 254 \\
\hline
\end{tabular}

Notes: $+p<0.10 ;{ }^{*} p<0.05 ;{ }^{* *} p<0.01 ;{ }^{* * *} p<0.001$.

\subsubsection{The Moderating Effect of Environmental Munificence}

We ran Model 3 and Model 6 (see Tables 3 and 4) to test Hypothesis 2 regarding the moderating effect of environmental munificence. In Model 3 and Model 6 of Table 3, the interaction between environmental munificence and family ownership $(F O \times E M)$ had a negative and significant effect on internationalization depth $(\beta=-0.292, p<0.05 ; \beta=-0.309, p<0.05)$, whereas the interaction between environmental munificence and family management $(F M \times E M)$ had a positive and significant effect on internationalization depth $(\beta=0.041, p<0.05 ; \beta=0.035, p<0.10)$. In Model 3 and Model 6 of Table 4, the interaction between environmental munificence and family management $(F M \times E M)$ had a negative 
and significant effect on internationalization breadth $(\beta=-0.114, p<0.05 ; \beta=-0.112, p<0.05)$, whereas the interaction between environmental munificence and family ownership $(F O \times E M)$ had no significant effect on internationalization breadth $(\beta=-0.220, p>0.10 ; \beta=-0.272, p>0.10)$.

To facilitate the interpretation, we divided the sample at the median for environmental munificence to form subgroups. Tables 5 and 6 show the multiple regression results of family involvement on internationalization for high versus low environmental munificence. With low environmental munificence, family ownership had a significantly positive effect on internationalization depth $(\beta=0.331, p<0.05)$, and the coefficient was greater than that with high environmental munificence $(\beta=0.172, p>0.10)$. Moreover, with low environmental munificence, family management had a significantly positive effect on internationalization breadth $(\beta=0.260, p<0.01)$, and the coefficient was greater than that with high environmental munificence ( $\beta=0.032, p>0.10$ ). In addition, with low environmental munificence, family management had a significantly positive effect on internationalization depth $(\beta=0.048, p<0.10)$, and the coefficient was less than that with high environmental munificence $(\beta=0.082, p<0.01)$.

Taken together, we found that environmental munificence can weaken the positive effect of family ownership on internationalization depth, as well as the positive effect of family management on internationalization breadth. Environmental munificence can intensify the positive effect of family management on internationalization depth. That is, as environmental munificence increases, the positive effect of family ownership on internationalization depth, as well as the positive effect of family management on internationalization breadth becomes weaker. However, the positive effect of family management on internationalization depth became stronger. The greater the family firm's internationalization breadth, the greater access the family firm will have to the resources needed for an extensive international market, and this reduced the resource support required from the industrial environment in the home country, thereby leading to a different effect of environmental munificence on the relationship between family management and internationalization breadth, and depth. Hypothesis 2 was then partially supported.

Table 5. Results of family involvement on the internationalization depth of Chinese family firms in subgroups.

\begin{tabular}{|c|c|c|c|c|c|c|}
\hline Variables & \multicolumn{2}{|c|}{ Environmental Munificence } & \multicolumn{2}{|c|}{ Institutional Environment } & \multicolumn{2}{|c|}{ Political Ties } \\
\hline -CONS & $-0.411(0.258)$ & $-0.071(0.252)$ & $-0.105(0.282)$ & $-0.062(0.228)$ & $0.056(0.406)$ & $-0.402^{+}(0.211)$ \\
\hline AGE & $0.026(0.051)$ & $0.036(0.045)$ & $0.019(0.051)$ & $-0.009(0.044)$ & $-0.045(0.095)$ & $0.022(0.035)$ \\
\hline PERF & $0.043(0.041)$ & $0.069(0.042)$ & $-0.004(0.045)$ & $0.076 *(0.037)$ & $0.168 *(0.062)$ & $-0.001(0.033)$ \\
\hline EM & & & $0.068^{+}(0.037)$ & $0.003(0.035)$ & $-0.061(0.057)$ & $0.069 *(0.027)$ \\
\hline IE & $0.054^{* *(0.017)}$ & $0.006(0.018)$ & & & $-0.019(0.026)$ & $0.043^{* *}(0.014)$ \\
\hline POL & $-0.049(0.088)$ & $0.028(0.082)$ & $-0.006(0.174)$ & $0.022(0.060)$ & & \\
\hline $\mathrm{FO}$ & $0.172(0.187)$ & $0.331 *(0.158)$ & $0.388 *(0.188)$ & $0.190(0.152)$ & $0.084(0.243)$ & $0.206(0.134)$ \\
\hline$N$ & 126 & 142 & 130 & 138 & 51 & 217 \\
\hline
\end{tabular}

Notes: $+p<0.10 ;{ }^{*} p<0.05 ;{ }^{* *} p<0.01 ;{ }^{* * *} p<0.001$. 
Table 6. Results of family involvement on the internationalization breadth of Chinese family firms in subgroups.

\begin{tabular}{|c|c|c|c|c|c|c|}
\hline \multirow{2}{*}{ Variables } & \multicolumn{2}{|c|}{ Environmental Munificence } & \multicolumn{2}{|c|}{ Institutional Environment } & \multicolumn{2}{|c|}{ Political Ties } \\
\hline & High & Low & Good & Bad & Yes & No \\
\hline$-\mathrm{CONS}$ & $\begin{array}{c}-1.319 \\
+(0.705)\end{array}$ & $\begin{array}{c}-1.951 \\
* *(0.703)\end{array}$ & $-0.625(0.637)$ & $-1.108(0.778)$ & $\begin{array}{c}-2.764 \\
*(1.258)\end{array}$ & $-0.726(0.559)$ \\
\hline SIZE & $-0.065(0.063)$ & $0.094(0.069)$ & $0.028(0.062)$ & $0.010(0.075)$ & $-0.140(0.105)$ & $0.074(0.052)$ \\
\hline AGE & $\begin{array}{c}0.372 \\
* *(0.139)\end{array}$ & $0.213(0.138)$ & $0.121(0.120)$ & $0.354(0.164)$ & $0.711 *(0.342)$ & $0.117(0.098)$ \\
\hline INDU & $0.104(0.203)$ & $0.204(0.222)$ & $0.366 *(0.164)$ & $0.091(0.250)$ & $-0.239(0.396)$ & $0.374 *(0.154)$ \\
\hline EIE & $0.055(0.174)$ & $\begin{array}{c}0.400 \\
+(0.207)\end{array}$ & $0.206(0.144)$ & $0.204(0.238)$ & $0.407(0.412)$ & $0.128(0.136)$ \\
\hline PERF & $\begin{array}{c}0.329 \\
* *(0.111)\end{array}$ & $0.068(0.118)$ & $-0.015(0.100)$ & $\begin{array}{c}0.357 \\
* *(0.125)\end{array}$ & $0.441 *(0.188)$ & $0.035(0.87)$ \\
\hline EM & & & $-0.110(0.082)$ & $-0.162(0.119)$ & $\begin{array}{c}-0.326 \\
+(0.174)\end{array}$ & $-0.098(0.073)$ \\
\hline IE & $0.044(0.046)$ & $0.023(0.050)$ & & & $0.081(0.080)$ & $0.050(0.037)$ \\
\hline POL & $0.029(0.240)$ & $0.078(0.236)$ & $0.195(0.391)$ & $0.041(0.208)$ & & \\
\hline $\mathrm{FO}$ & $0.258(0.508)$ & $\begin{array}{c}0.859 \\
+(0.453)\end{array}$ & $0.891 *(0.420)$ & $0.348(0.537)$ & $\begin{array}{c}1.473 \\
+(0.746)\end{array}$ & $0.349(0.361)$ \\
\hline FM & $0.032(0.067)$ & $\begin{array}{c}0.260 \\
* *(0.075)\end{array}$ & $\begin{array}{c}0.200 \\
* * *(0.055)\end{array}$ & $0.059(0.099)$ & $0.207(0.145)$ & $\begin{array}{c}0.141 \\
* *(0.051)\end{array}$ \\
\hline$R^{2}$ & 0.167 & 0.226 & 0.235 & 0.179 & 0.512 & 0.152 \\
\hline Adjusted $R^{2}$ & 0.101 & 0.168 & 0.176 & 0.116 & 0.400 & 0.113 \\
\hline$F$ & 2.537 * & $3.893 * * *$ & $3.995^{* * *}$ & $2.829 * *$ & $4.554^{* * *}$ & $3.884 * *$ \\
\hline$N$ & 124 & 130 & 127 & 127 & 49 & 205 \\
\hline
\end{tabular}

\subsubsection{The Moderating Effect of Institutional Environment}

We ran Model 4 and Model 6 (see Tables 3 and 4) to test Hypothesis 3 regarding the moderating effect of the institutional environment. In Model 4 and Model 6 of Table 3, the interaction between institutional environment and family management $(F M \times I E)$ had a positive and significant effect on internationalization depth $(\beta=0.027, p<0.05 ; \beta=0.023, p<0.05)$, whereas the interaction between institutional environment and family ownership $(F O \times I E)$ had no significantly positive effect on internationalization depth $(\beta=0.039, p>0.10 ; \beta=0.040, p>0.10)$. In Model 4 and Model 6 of Table 4, the interaction between institutional environment and family management $(F M \times I E)$ had a positive and significant effect on internationalization breadth $(\beta=0.053, p<0.10 ; \beta=0.070, p<0.05)$, whereas the interaction between institutional environment and family ownership $(F O \times I E)$ had no significant effect on internationalization breadth $(\beta=-0.158, p>0.10 ; \beta=0.005, p>0.10)$.

To facilitate the interpretation, we divided the sample at the median for institutional environment to form subgroups. Tables 5 and 6 show the multiple regression results of family involvement on internationalization for good versus bad institutional environment. With good institutional environment, family management had a significantly positive effect on internationalization depth ( $\beta=0.069, p<0.01)$, and the coefficient was greater than that with a bad institutional environment $(\beta=0.005, p>0.10)$. Moreover, with a good institutional environment, family management had a significantly positive effect on internationalization breadth $(\beta=0.200, p<0.001)$, and the coefficient was greater than that with a bad institutional environment $(\beta=0.059, p>0.10)$.

Taken together, we found that the institutional environment can intensify the positive effects of family management on internationalization depth and breadth. That is, as institutional environment in the home country improves, the positive effects of family management on internationalization depth and breadth becomes stronger. Hypothesis 3 was thus partially supported. In addition, Table 3 also reveals that institutional environment positively impacts on the internationalization depth of 
Chinese family firms. Thus, our result partially fosters a view of institutions that suggests a favorable institutional setting can promote internationalization of Chinese private firms [14].

\subsubsection{The Moderating Effect of Political Ties}

We ran Model 5 and Model 6 (see Tables 3 and 4) to test Hypothesis 4 regarding the moderating effect of political ties. In Model 5 and Model 6 of Table 3, the interaction between political ties and family management $(F M \times P O L)$ had a negative and significant effect on internationalization depth $(\beta=-0.098, p<0.05 ; \beta=-0.067, p<0.10)$, whereas the interaction between political ties and family ownership $(F O \times P O L)$ had no significantly positive effect on internationalization depth $(\beta=0.053$, $p>0.10 ; \beta=0.243, p>0.10$ ). In Model 5 and Model 6 of Table 4, the interaction between political ties and family ownership $(F O \times P O L)$ had a positive and significant effect on internationalization breadth $(\beta=2.148, p<0.01 ; \beta=2.375, p<0.01)$, whereas the interaction between political ties and family management $(F M \times P O L)$ had no significantly positive effect on internationalization breadth $(\beta=0.067, p>0.10 ; \beta=0.124, p>0.10)$.

To facilitate the interpretation, we divided the sample with or without political ties to form subgroups. Tables 5 and 6 show the multiple regression results of family involvement on internationalization with or without political ties. For the family firms without political ties, family management had a significantly positive effect on internationalization depth $(\beta=0.076, p<0.001)$, and the coefficient was greater than that for the family firms with political ties $(\beta=0.011, p>0.10)$. Moreover, for the family firm with political ties, family ownership had a significantly positive effect on internationalization breadth $(\beta=1.473, p<0.10)$, and the coefficient was greater than that for the family firms without political ties $(\beta=0.349, p>0.10)$.

Taken together, we found that political ties can intensify the positive effect of family ownership on internationalization breadth, but that they weaken the positive effect of family management on internationalization depth. This means that as political ties increase, the positive effect of family ownership on internationalization breadth becomes stronger, whereas the positive effect of family management on internationalization depth becomes weaker. Hypothesis 4 was then partially supported.

In addition, Tables 3 and 4 reveal that there were no significantly direct effects of political ties on internationalization depth and breadth. The weakening role of political ties on the relationship between family management and internationalization depth was reflected by the negative effect of political ties. That is, political ties for political rent-seeking and other non-productive activities [43], may inhibit the internationalization of Chinese family firms. The strengthening role of political ties on the relationship between family ownership and internationalization breadth was reflected by the positive effect of political ties. That is, political ties for resource supply effect $[18,19]$ may facilitate the internationalization of Chinese family firms. With both positive and negative effects, political ties showed no significantly direct effects on internationalization depth and breadth of Chinese family firms.

\section{Discussions and Conclusions}

Internationalization is widely acknowledged as an important strategy for a family firm's long-term survival and sustainable growth. Currently, a growing number of studies have investigated the effect of family involvement on family firm internationalization [1]. However, these studies focus on family firms in developed countries; there has been little research into the effect of family involvement on Chinese family firm internalization. In this study, we explored the effects of two dimensions of family involvement (i.e, family ownership and family management) on Chinese family firm internationalization (i.e., internationalization depth and internationalization breadth), examining the moderating effects of environmental munificence, institutional environment, and political ties in this relationship. Drawing on the data of 274 family firms in 8 provinces or municipalities of China, the study yields 4 major conclusions:

First, family ownership and management positively impacted internationalization depth and breadth. This result was in line with previous research $[2,3,26]$, but it did not support the viewpoint 
that family management negatively influences family firm internationalization $[5,8,25]$. Second, environmental munificence weakened the effect of family ownership on internationalization depth, as well as the effect of family management on internationalization breadth, whereas environmental munificence intensified the effect of family management on internationalization depth. That is, as environmental munificence increased, the positive effect of family ownership on internationalization depth, as well as the positive effect of family management on internationalization breadth, became weaker, whereas the positive effect of family management on internationalization depth became stronger. Third, the institutional environment intensified the effects of family management on internationalization depth and breadth. That is, as institutional environment in the home country improved, the positive effects of family management on internationalization depth and breadth became stronger. Fourth, political ties weakened the effect of family management on internationalization depth, but intensified the effect of family ownership on internationalization breadth. That is, as political ties increased, the positive effect of family management on internationalization depth became weaker, whereas the positive effect of family ownership on internationalization breadth became stronger.

This study makes three important contributions to the literature. Firstly, this study extends the literature on the development of family firm internationalization in emerging economies, especially in China. Prior research has largely been conducted in developed economies [1]. Very limited research on Chinese family firms also ignores the moderating effects of industrial and institutional environments in the above relationship $[10,11]$. This paper has embraced how family ownership and family management influence internationalization, as well as their unique situational mechanism in China. Drawing on a large sample of family firms from eastern and western China, it is indicated that family involvement has a different effect on internationalization in emerging and developed economies. Most empirical studies in developed economies support the negative effect of family involvement on the internationalization of family firms $[4,8,23]$. Our research highlights the importance of family ownership, family management, environmental munificence, institutional environment, and political ties for the internationalization of Chinese family firms, thus providing a new and more realistic insight for family firms' motivation for internationalization in emerging economies.

Secondly, this study adds to the empirical evidence with regards to the significant role of institutional environments in Chinese family firm internationalization. Differing from the traditional analysis of institutions that mainly emphasize formal institutions such as law and policy, our study considers both formal and informal institutions by probing into the moderating effects of the degree of marketization and political ties. Furthermore, we find that entrepreneurs' political ties weaken the positive effect of family management on internationalization depth, but intensify the positive effect of family ownership on internationalization breadth. The weakening role of political ties is reflected in the negative effect of political ties. That is, political ties for political rent-seeking and other non-productive activities [43] may inhibit internationalization. The strengthening role of political ties is reflected in the positive effect of political ties. That is, political ties for resource supply may facilitate internationalization. Most previous research has emphasized the positive effect of political ties on Chinese firms $[18,19]$. Therefore, this study also adds to prior research on private entrepreneurs' political ties in emerging economies.

Finally, this paper examined the influence of family ownership and family management on both internationalization depth and breadth, two conceptually different facets of family involvement and internationalization strategy, thereby providing a more fine-grained understanding of the impact of family involvement on Chinese family firm internationalization.

This study also has several practical implications. First, our findings suggest that family has a similar effect in both emerging and developed economies. Therefore, it is necessary to enhance our understanding of how family contributes to Chinese family firm internationalization. Currently, family ownership and management are still important governance mechanisms for the internationalization of Chinese family firms. Therefore, Chinese family firms should carefully implement reforms of corporate governance, for example, in avoiding prematurely or excessively diluting family equity 
and considering the hiring of nonfamily professionals. Second, our study shows that political ties are not always productive. Accordingly, Chinese family firms should rationally maintain the autonomy of political embedding. On the one hand, Chinese family firms should avoid using political ties for political rent-seeking and other non-productive activities, so as to reduce the negative effect of political ties on internationalization. On the other hand, Chinese family firms should utilize their political ties to acquire scarce resources and establish organizational legitimacy in the international market. Finally, our findings encourage government agencies in emerging economies to establish industrial and institutional environments in the home country that are fair to different types of enterprises.

Despite the contributions, this study has several limitations that may provide opportunities for future research. First, this study only considered the direct effect of family involvement on internationalization, but did not consider the mediating mechanism through which family involvement influences family firm internationalization. Previous studies assumed that family involvement impacted on the accumulation of resources and capabilities, as well as socioemotional wealth protection, thus influencing family firm internationalization [1]. Therefore, it would be interesting to expand the model by incorporating some mediating variables that likely impact the internationalization of family firms. Second, the measurement of internationalization only involved the degree of internationalization, but did not consider internationalization speed and mode (e.g., export, OFDIs). The measurement of industrial environment only involved environmental munificence in the home country, and thus ignored environmental dynamics in the home country, as well as the industrial environment in the host country. The measurement of institutional environment only involved the institutional environment in the home country. Specifically, we chose the degree of marketization and political ties as substitute variables for formal and informal institution in the home country, but did not consider the institutional environment in the host country. Therefore, further research might provide additional insights if more sophisticated measurements are conducted for internationalization, industrial, and institutional environments.

Author Contributions: Conceptualization, L.Z., Y.H., and C.G.; investigation, L.Z., Y.H., and C.G.; methodology, L.Z.; writing—original draft preparation, Z.L.; writing—review and editing, Y.H. and C.G.; All authors contributed to the writing of the paper.

Funding: The authors are grateful to the financial support provided by the National Social Science Foundation of China (15BGLO15, 19BGL077).

Conflicts of Interest: The authors declare no conflict of interest.

\section{References}

1. Pukall, T.J.; Calabrò, A. The internationalization of family firms: A critical review and integrative model. Fam. Bus. Rev. 2014, 27, 103-125. [CrossRef]

2. Zahra, S.A. International expansion of US manufacturing family business: The effect of ownership and involvement. J. Bus. Venturing 2003, 18, 495-512. [CrossRef]

3. Carr, C.; Bateman, S. International strategy configurations of the world's top family firms. Manag. Int. Rev. 2009, 49, 733-758. [CrossRef]

4. Fernández, Z.; Nieto, M.J. Internationalization strategy of small and medium-sized family business: Some influential factors. Fam. Bus. Rev. 2005, 18, 77-89. [CrossRef]

5. Graves, C.; Thomas, J. Internationalization of Australian family businesses: A managerial capabilities perspective. Fam. Bus. Rev. 2006, 19, 207-224. [CrossRef]

6. Sciascia, S.; Mazzola, P.; Astrachan, J.H.; Pieper, T.M. The role of family ownership in international entrepreneurship: Exploring nonlinear effects. Small Bus. Econ. 2012, 38, 15-31. [CrossRef]

7. Pinho, J.C. The impact of ownership: Location specific advantages and managerial characteristics on SME foreign entry mode choices. Int. Market. Rev. 2007, 24, 715-734. [CrossRef]

8. Cerrato, D.; Piva, M. The internationalization of small and medium-sized enterprises: The effect of family management, human capital and foreign ownership. J. Manag. Govern. 2012, 16, 617-644. [CrossRef] 
9. Arregle, J.L.; Duran, P.; Hitt, M.A.; Essen, M. Why is family firms' internationalization unique? A meta-analysis. Entrep. Theory Pract. 2017, 41, 801-831. [CrossRef]

10. Liang, X.Y.; Wang, L.H.; Cui, Z.Y. Chinese private firms and internationalization: Family involvement in management and family ownership. Fam. Bu. Rev. 2014, 27, 126-141. [CrossRef]

11. Dou, J.S.; Jacoby, G.; Li, J.L.; Su, Y.Y.; Wu, Z.Y. Family involvement and family firm internationalization: The moderating effects of board experience and geographical distance. J. Int. Financ. Mark. Inst. Money 2019, 59, 250-261. [CrossRef]

12. Debicki, B.J. Socioemotional Wealth and Family Firm Internationalization: The Moderating Effect of Environmental Munificence. Ph.D. Thesis, Mississippi State University, Mississippi State, MS, USA, May 2012.

13. Deng, P.; Wu, B. Institutional escapism and internationalization of SMEs: Evidence from Chinese private firms. Acad. Manag. Annu. Meet. Proc. 2016, 1, 12999.

14. Li, F.G.; Ding, D. The dual effects of home country institutions on the internationalization of private firms in emerging markets: Evidence from China. Mult. Bus. Rev. 2017, 25, 128-149. [CrossRef]

15. Xin, K.R.; Pearce, J.L. Guanxi: Connection as substitutes for formal institutional support. Acad. Manag. J. 1996, 39, 1641-1658.

16. Peng, M.W.; Luo, Y. Managerial ties and firm performance in a transition economy: The nature of a micro-macro link. Acad. Manag. J. 2000, 43, 486-501.

17. Kafouros, M.I.; Buckley, P.J.; Clegg, J. The effects of global knowledge reservoirs on the productivity of multinational enterprises: The role of international depth and breadth. Res. Policy 2012, 41, 848-861. [CrossRef]

18. Chen, X.; Wu, J. Do differential guanxi types affect capability building differently? A contingency view. Ind. Market. Manag. 2011, 40, 581-592. [CrossRef]

19. Li, H.; Zhang, Y. The role of managers' political networking and functional experience in new venture performance: Evidence from China's transition economy. Strategic Manag. J. 2007, 28, 791-804. [CrossRef]

20. Calabrò, A.; Torchia, M.; Pukall, T.; Mussolino, D. The influence of ownership structure and board strategic involvement on international sales: The moderating effect of family involvement. Int. Bus. Rev. 2013, 22, 509-523. [CrossRef]

21. Graves, C.; Thomas, J. Determinants of the internationalization pathways of family firms: An examination of family influence. Fam. Bus. Rev. 2008, 21, 151-167. [CrossRef]

22. Miller, D.; Le Breton-Miller, I.; Scholnick, B. Stewardship vs. stagnation: An empirical comparison of small family and non-family businesses. J. Manag. Stud. 2008, 45, 51-78. [CrossRef]

23. Claver, E.; Rienda, L.; Quer, D. Family firms risk perception: Empirical evidence on the internationalization process. J. Small Bus. Enterp. Dev. 2008, 15, 457-471. [CrossRef]

24. Fernández, Z.; Nieto, M.J. Impact of ownership on the international involvement of SMEs. J. Int. Bus. Stud. 2006, 37, 340-351. [CrossRef]

25. Ray, S.; Mondal, A.; Ramachandran, K. How does family involvement affect a firm' internationalization? An investigation of Indian family firms. Glob. Strateg. J. 2018, 8, 73-105. [CrossRef]

26. Fang, H.; Kotlar, J.; Memili, E.; Chrisman, J.J.; De Massis, A. The pursuit of international opportunities in family firms: Generational differences and the role of knowledge-based resources. Glob. Strateg. J. 2018, 8, $136-157$. [CrossRef]

27. Sirmon, D.G.; Hitt, M.A. Managing resources: Linking unique resources, management, and wealth creation in family firms. Entrep. Theory Pract. 2003, 27, 339-358. [CrossRef]

28. Segaro, E. Internationalization of family SMEs: The impact of ownership, governance, and top management team. J. Manag. Govern. 2012, 16, 147-169. [CrossRef]

29. Family Business Research Group of Chinese Private Economy Research Association. Chinese Family Business Report; China CITIC Press: Beijing, China, 2011. (In Chinese)

30. Redding, G. Weak Organization and Strong Linkages: Managerial Ideology and Chinese Family Firm Networks. In Business Networks and Economic Development in East and Southeast Asian; Hamilton, G.G., Ed.; Centre of Asian Studies, University of Hong Kong: Hong Kong, China, 1991.

31. Okoroafo, S.C. Internationalization of family businesses: Evidence from Northwest Ohio, U.S.A. Fam. Bus. Rev. 1999, 12, 147-158. [CrossRef]

32. Acquaah, M. Social networking relationships, firm-specific managerial experience and firm performance in a transition economy: A comparative analysis of family owned and nonfamily firms. Strategic Manag. J. 2012, 33, 1215-1228. [CrossRef] 
33. Graves, C.; Shan, Y.G. An empirical analysis of the effect of internationalization on the performance of unlisted family and nonfamily firms in Australia. Fam. Bus. Rev. 2014, 27, 142-160. [CrossRef]

34. Chang, S.J.; Shim, J. When does transitioning from family to professional management improve firm performance? Strategic Manag. J. 2015, 36, 1297-1316. [CrossRef]

35. Dess, G.; Beard, D. Dimensions of organizational task environments. Admin. Sci. Quart. 1984, 29, 52-78. [CrossRef]

36. North, D.C. Institutions, Institutional Change, and Economic Performance; Cambridge University Press: Cambridge, UK, 1990.

37. Yamakawa, Y.; Peng, M.W.; Deeds, D.L. What drives new ventures to internationalize from emerging to developed economies? Entrep. Theory Pract. 2008, 32, 59-82. [CrossRef]

38. Holmes, R.M.; Miller, T.; Hitt, M.A.; Salmador, M.P. The interrelationships among informal institutions, formal institutions, and inward foreign direct investment. J. Manag. 2013, 39, 531-566. [CrossRef]

39. Boisot, M.; Meyer, M.W. Which way through the open door? Reflections on the internationalization of Chinese firms. Manag. Organ. Rev. 2008, 4, 349-365. [CrossRef]

40. Sheng, S.; Zhou, K.Z.; Li, J.J. The effects of business and political ties on firm performance: Evidence from China. J. Mark. 2011, 75, 1-15. [CrossRef]

41. Peng, M.W.; Heath, P.S. The growth of the firm in planned economies in transition: Institutions, organizations and strategic choice. Acad. Manag. Rev. 1996, 21, 492-528. [CrossRef]

42. Napshin, S.A.; Azadegan, A. Partner attachment to institutional logics: The influence of congruence and divergence. J. Manag. Organ. 2012, 18, 481-498. [CrossRef]

43. Wang, C.; Yi, J.; Kafouros, M.; Yan, Y. Under what institutional conditions do business groups enhance innovation performance. J. Bus. Res. 2015, 68, 694-702. [CrossRef]

44. Yuan, J.G.; Hou, Q.S.; Cheng, C. The curse effect of enterprise political resources: Based on the investigation of political association and firms' technological innovation. Manag. Word 2015, 1, 139-155. (In Chinese)

45. Westhead, P.; Howorth, C. Ownership and management issues associated with family firm performance and company objectives. Fam. Bus. Rev. 2006, 19, 301-316. [CrossRef]

46. Wang, X.L.; Fan, G.; Yu, J.W. Marketization Index of China's Provinces: NERI Report 2016; Social Sciences Academic Press: Beijing, China, 2017. (In Chinese)

47. Du, X.; Luo, J. Political connections, home formal institutions and internationalization: Evidence from China. Manag. Organ. Rev. 2016, 12, 103-133. [CrossRef]

48. Gómez-Mejía, L.R.; Makri, M.; Larraza-Kintana, M. Diversification decisions in family-controlled firms. J. Manag. Stud. 2010, 47, 223-252. [CrossRef]

49. Aiken, L.S.; West, S.G. Multiple Regression: Testing an Interpreting Interactions; Sage Publications: Newbury Park, CA, USA, 1991.

50. Kutner, M.H.; Nachtsheim, C.J.; Neter, J. Applied Linear Regression, 4th ed.; McGraw-Hill Irwin: New York, NY, USA, 2004.

(C) 2019 by the authors. Licensee MDPI, Basel, Switzerland. This article is an open access article distributed under the terms and conditions of the Creative Commons Attribution (CC BY) license (http://creativecommons.org/licenses/by/4.0/). 